\title{
Role of calcimicrobes and microbial carbonates in the Late Carboniferous (Moscovian) mounds in southern Guizhou, South China
}

Wen-Tao Huang ${ }^{1}$, Yong-Li Zhang ${ }^{1}$, Chang-Qing Guan ${ }^{1}$, Zhuo-Wei Miao ${ }^{1}$, Xiao-Hong Chen ${ }^{2}$, Zhen-Yuan Yang ${ }^{1}$, Xiao $\mathrm{Li}^{1}$ and En-Pu Gong ${ }^{1 *}$

\begin{abstract}
Various microbial fabrics characterize late Moscovian mounds in Houchang Town, southern Guizhou, South China. The dominant components of the mounds are microbial boundstones with stromatolitic structures, irregular oncoid-like forms, and wrinkle structures. Calcimicrobes recognized in the mounds include Girvanella, Ortonella, Wetheredella-like, Palaeomicrocodium-like, and some problematic calcimicrobes occurring in deposits between microbial boundstones, in thrombolitic textures, and in some intraclasts. Microbial carbonates are common in the substrate and interior of the mounds, including thrombolitic textures, microstromatolites, microbial ooids, oncoids, irregular encrusted layers, microbial mat debris, and microbial micrite. Calcimicrobes and microbial carbonates played an important role in the construction of the mounds: Girvanella might have contributed as a source of lime mud that formed the mound and stabilized the coral frame; thrombolitic mats could trap and fix sediments and bioclasts, contributing to the stabilization of substrate and mound limestones; and, microbial boundstone, clotted micrite and micritized bioclast could provide a hard substrate for encrusting metazoans (e.g., bryozoans, Ivanovia). The abundant microbial fabrics in the mounds indicate that microbial activity was widespread in Moscovian reef mounds in southern Guizhou, and this suggests that microbial organisms were the primary mound builders in the study area.
\end{abstract}

Keywords: Microfossils, Microbial carbonates, Mounds, Late Carboniferous, Moscovian, Guizhou

\section{Introduction}

Carboniferous reef systems were not as active as thriving Devonian and Permian reefs. Following a collapse in the Late Devonian, Waulsortian mounds dominated by lime mud, without rigid organic skeletal framework, were the main organic buildups during the Early Mississippian (Lees 1961, 1964, 1997; Miller 1986; West 1988; Gong et al. 2010). Framework reefs and relatively balanced reef-building guilds gradually returned in the Visean (Fagerstrom 1994; Webb 2002; Chevalier and Aretz 2005; Gong et al. 2010). Corals, bryozoans, sponges, and calcareous algae were the common reef builders (Fang and

\footnotetext{
* Correspondence: gongep@mail.neu.edu.cn

${ }^{1}$ College of Resources and Civil Engineering, Northeastern University,

Shenyang 110819, Liaoning Province, China

Full list of author information is available at the end of the article
}

Hou 1985; Webb 2002; Gong et al. 2004, 2010; Chen et al. 2013; Yao and Wang 2016). By the Moscovian, metazoan reefs were more complete, when chaetetids and corals became the dominant frame-building organisms (West 1988; Gong et al. 2010, 2012). After the sudden decrease in the number of chaetetids in the end-Moscovian, phylloid algae took the leading "role" in reefs during the Late Pennsylvanian (West 1988; Gong et al. 2010).

In South China, Carboniferous reefs developed mainly in Guangxi and southern Guizhou (Fang and Hou 1985; Gong et al. 2004, 2010; Shen and Qing 2010; Chen et al. 2013; Yao and Wang 2016). Carboniferous reefs in South China showed both uniqueness and common characteristics compared to those elsewhere. Only a few Waulsortian-like mud banks of the Lower Mississippian were previously described by Aretz et al. (2012). Reef 
building underwent a short recovery episode during the Visean, when several bryozoan-coral, coral biostromes/ reefs, and stromatolite mounds developed (Fang and Hou 1985; Zhou and Zhang 1991; Shen and Qing 2010; Chen et al. 2013; Yao and Wang 2016; Yao et al. 2016). Nevertheless, reefs were rarely reported in South China from the Upper Mississippian to the Lower Pennsylvanian, except for some stromatolites in Hunan Province (Liu 2002; Yao and Wang 2016). No chaetetid reefs from the Moscovian, which were the main organic buildups in North China, America and Japan (Suchy and West 1988, 2001; West 1988; Nakazawa 2001; Wang et al. 2017), were documented in South China; only a few coral patch reefs and red algal reefs from the Dabu Formation and the Huanglong Formation in Guangxi have been described (Zeng 1996; Yang et al. 2013, 2014; Wang et al. 2014; Yao and Wang 2016). However, a distinct increase in the type and number of reefs occurred during the Late Pennsylvanian. Various reefs from the upper Kasimovian-Gzhelian were exposed in Houchang Town, southern Guizhou (Gong et al. 2004, 2007a, b; Guan et al. 2004, 2006, 2010; Sun et al. 2007; Zhang et al. 2007; Yao and Wang 2016), which may imply that the Late Carboniferous reefs were thriving, relatively, in South China.

The mounds dominated by microbial carbonates and algae described here were exposed in Houchang Town, Ziyun County, southern Guizhou. The rugose coral (Ivanovia) was also present in one of these mounds as reported by Guan et al. (2007), although the age of this mound has not been confirmed and the main builder (an algal-like organism) was not precisely defined (Guan et al. 2007). In this study we describe various calcimicrobes and microbial carbonates in these mounds in detail and discuss their role as mound-builders. This is the first report of microbial mounds from the Upper Carboniferous in the study area.

\section{Geological background}

During the Late Carboniferous, South China was characterized by an extended shallow carbonate platform that consisted of Southwest, South Central, Yangtze, Longmenshan, and Western Yunnan platforms (Feng et al. 1999) (Fig. 1a). The study area is situated in Houchang Town, Ziyun County, southern Guizhou, tectonically in the Southwest Platform of South China. Strata from the Upper Carboniferous to the Permian are well preserved in the study area, which were representative of shallow marine deposits composed of light grey, medium- to thick-bedded massive limestones (Bureau of Geology and Mineral Resources of Guizhou Province 1987; Wu 1987). The Upper Carboniferous sequences, consisting of Weining and Maping formations, contained abundant fossils (Bureau of Geology and Mineral Resources of Guizhou Province 1987) . Many well-preserved reefs in the topmost Carboniferous
(Kasimovian-Gzhelian), have been studied previously (Gong et al. 2004, 2007a, b; Guan et al. 2004, 2006, 2007, 2010; Sun et al. 2007; Zhang et al. 2007).

The two mounds dominated by microbial carbonates described in this paper were located near Lumazhai and Zhongxinzhai villages, respectively (Fig. 1b). A detailed study of the fusulinids was undertaken, and Fusulinella helenae, F. paracolaniae, F. pseudobocki, F. soligalichi, Pseudostaffella cuboides, P. panxianensis, P. paradoxa, Schubertella ginki exilis, S. magna, Ozawainella vozhgalica, Pseudoendothyra spp., and Wedekindellina spp. were recognized in Lumazhai and Zhongxinshai sections that correspond to the Fusulina pakhrensis-Pseudostaffella paradoxa Subzone in the Fusulinella-Fusulina Zone, establishing the age of the two mounds as late Moscovian (Fig. 1c) (Zhang and Zhou 2004). The Fusulina pakhrensis-Pseudostaffella paradoxa Subzone can be correlated with the Beedeina kamensis-Putrella brazhnikovae and Fusulinella bocki-F. rara-Beedeina samarica subzones developed during the same age in Russia (Fig. 1c) (Zhang and Zhou 2004).

\section{General description of the mounds}

\subsection{Lumazhai mound}

The mound situated in Lumazhai village (GPS: $25^{\circ} 30^{\prime}$ $27.0^{\prime \prime} \mathrm{N}, 106^{\circ} 14^{\prime} 02.0^{\prime \prime} \mathrm{E}$ ) is about $19 \mathrm{~m}$ thick, extends about $30 \mathrm{~m}$ laterally, and is composed mainly of grey thick-bedded microbial carbonate and phylloid algae boundstone. There is a distinct variation in the builders and composition of this mound, which helped us recognize three vertical growth stages in ascending order: Stage I, Stage II and Stage III (Fig. 2).

The substrate is composed of grey thick-bedded wackestone and packstone. Peloids, microbial mat debris and bioclasts constitute most of the volume of the lower part (Fig. 3a). Diverse bioclasts, including bryozoans, small brachiopod shells, a few gastropods, ostracods, crinoids, and foraminifera, are recognized although they are not very abundant. The substrate becomes clotted wackestone towards the mound and the biodiversity decreases. Most of the skeletal grains have micritic envelopes (Fig. 3b).

The massive microbial boundstone with an algal-like texture is the most distinguishing characteristic of Stage I. It formed two types of assemblages in the field: stromatolitic boundstone and irregular oncoid-like boundstone (Fig. 4a, b). The stromatolitic boundstone has an undulating outline that extends to $1.5 \mathrm{~m}$ laterally. The boundstone is mostly horizontal, domical, and or irregular in shape, and contains few fossils. It can also coat a nucleus, which is usually formed by tube-shaped algae, crinoid fragments, bryozoans, brachiopods, and lithoclasts, to produce an irregular oncoid appearance (Fig. $4 \mathrm{~b})$. The spaces between the algal-like assemblages are 


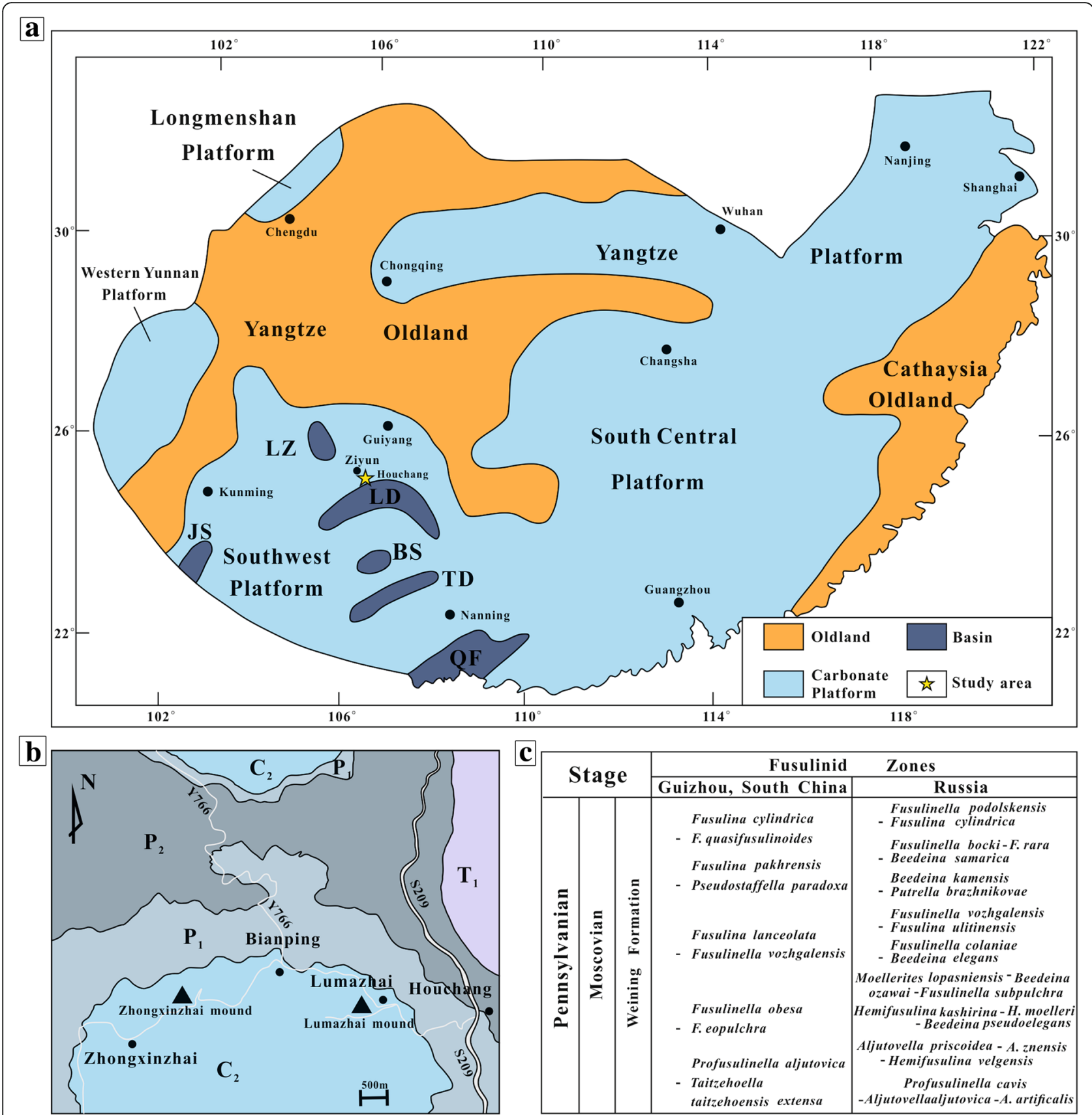

Fig. 1 Geological background information of this study. a The Late Carboniferous palaeogeography of South China (after Feng et al. 1999) and the location of the study area; BS = Baise Basin, JS = Jianshui Basin, LD = Luodian Basin, LZ = Liuzhi Basin, QF = Qinfang Basin, TD = Tiandeng Basin; b A geological map of the study area and the locations of Lumazhai and Zhongxinzhai mounds. $C_{2}=$ Upper Carboniferous, $P_{1}=L$ Lower Permian, $P_{2}=$ Upper Permian, $T_{1}=$ Lower Triassic; Y766 $=766$ Village Road, S209=209 Provincial Road; $\mathbf{c}$ Fusulinid zones of the Weining Formation in the study area and comparison to Russia

filled with bioclastic-peloid and thrombolitic wackestone, and microbial mud.

The microbial boundstone occupies relatively smaller percentage of the mound in Stage II when compared with Stage I. The diversity and abundance of the organisms increase abruptly, with corals, calcimicrobes, bryozoans, chaetetids, phylloid algae, and crinoids constituting a significant part of Stage II (Fig. 4c). Well-preserved small-scale coral frameworks are distributed mostly in the flanks of the mound, while crinoids are well preserved at its core.

Stage III is dominated by a $2.5 \mathrm{~m}$-thick phylloid algae boundstone that extends $10 \mathrm{~m}$ laterally (Fig. $4 \mathrm{~d}$ ). The well-preserved algal thalli are 5-12 cm long individually and show characteristics of growing autochthonously. 

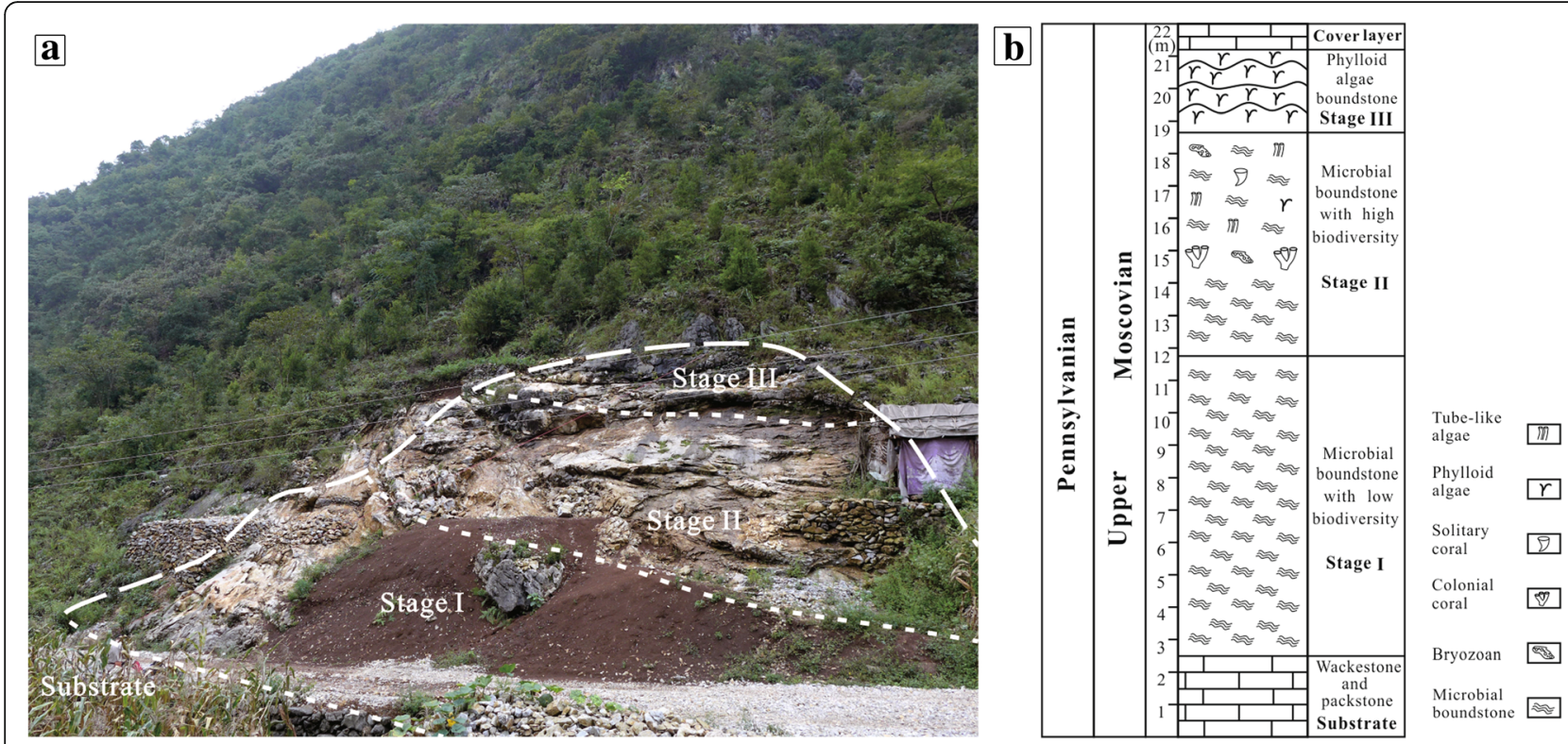

Fig. 2 Overview of the Lumazhai mound. a Outcrop photograph of the Lumazhai mound with three stages. The log cabin in the right part of the photo is about $2.5 \mathrm{~m}$ high; $\mathbf{b}$ Stratigraphic column of the Lumazhai mound

Many cavities in the phylloid algae boundstone and widespread marine cements also indicate that the algae developed in situ (Fig. 3c).

\subsection{Zhongxinzhai mound}

The mound near Zhongxinzhai village (GPS: $25^{\circ} 30^{\prime}$ $33.5^{\prime \prime} \mathrm{N}, 106^{\circ} 12^{\prime} 08.0^{\prime \prime} \mathrm{E}$ ) is much larger than the Lumazhai mound; it is about $15 \mathrm{~m}$ in thickness and extends more than $200 \mathrm{~m}$ in lateral direction, as briefly reported by Guan et al. (2007). The substrate consists of massive bioclastic wackestone and packstone. Peloids, microbial mat debris, crinoids, foraminifera, bryozoans, brachiopod shells, gastropods, and algae are recognized. Many fossils are highly micritized. A phylloid algae patch reef, $2 \mathrm{~m}$ thick and $8 \mathrm{~m}$ wide, developed at the base of the Zhongxinzhai mound, and the well preserved algal thalli and synsedimentary cavities indicate an in situ buildup. Microbial boundstone with algal-like texture and colonial rugose coral (Ivanovia) communities dominate the main part of the mound (Figs. 5 and 6).

\section{Calcimicrobes and microbial carbonates}

Well-preserved calcimicrobes and microbial carbonates are important components of the Lumazhai and Zhongxinzhai mounds. The calcimicrobes occur mainly in deposits between microbial boundstone, in peloid wackestone or packstone, in micritized bioclastic-intraclastic packstone, and in thrombolitic textures, forming varied microbial products including microbial fabrics, thrombolitic textures, microstromatolites, encrustation, oncoids, and microbial ooids.

\subsection{Calcimicrobes}

The calcimicrobes recognized in this study belong mostly to the porostromate group (Riding 1991), and include Girvanella (Wood 1957; Riding 1977), Ortonella (Riding 1991), Wetheredella-like, Palaeomicrocodiumlike, and Tubiphytes-like organisms, as well as some problematic calcimicrobes.

Girvanella, which have a tubular outline with micritized sheaths, are ubiquitous in the mounds. The nonbranching tubes in this study are circular in transverse section and range from $15 \mu \mathrm{m}$ to $40 \mu \mathrm{m}$ in diameter. Girvanella are preserved in four styles in the mound complexes: boundstone, intraclasts, crusts, and borers. Girvanella boundstone is common in the Lumazhai mound and has a micritic texture dominated by tubular thalli (Fig. 7a). The thalli, which make up about 50\%-60\% of the volume of the boundstone, are about $30 \mu \mathrm{m}$ in diameter and intertwined in a disorderly manner. The Girvanella intraclasts occur in micritized bioclastic-intraclastic wackestone-packstone, making up about $5 \%$ of its volume. The Girvanella thalli are $~ 30-40 \mu \mathrm{m}$ in diameter (Fig. 7b). In some clasts, the thalli have been strongly micritized and show fuzzy tubular outlines. The tangled Girvanella tubes could be wrapped around the skeletal grains and hard substrates to form the encrustations. Another kind of crust composed of abundant tubular thalli is also found in the coral frameworks (Fig. 7c). These thalli are around $30 \mu \mathrm{m}$ in diameter, which jointed the individual coral and filled the growth cavities in the framework (Fig. 7d). Girvanella-like calcimicrobe tubes also act on the carbonate grains as borers; thalli around $40 \mu \mathrm{m}$ in diameter bore into the 

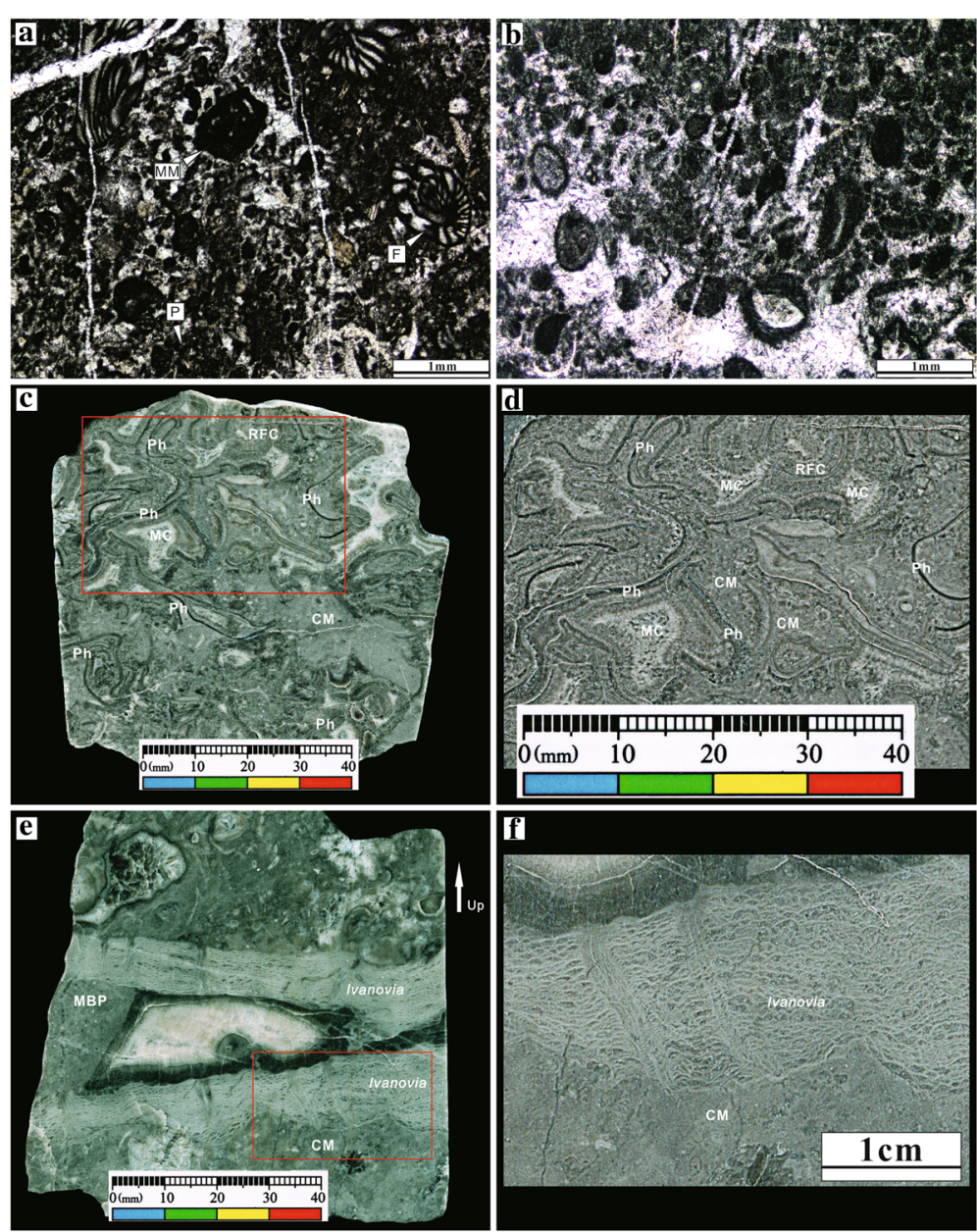

Fig. 3 Thin-section photographs of the Lumazhai mound substrate and some polished slabs. a Thin-section photograph of the Lumazhai mound substrate with peloids (P), microbial mat debris (MM), and foraminifera (F); b Thin-section photograph of the Lumazhai mound substrate: most of the skeletal grains have micritic envelopes; c Polished slabs of phylloid algae boundstone: clotted micrite (CM), mosaic cement (MC), phylloid algae (Ph), radiaxial fibrous cement (RFC); $\mathbf{d}$ Details of the red box in (c); e Polished slabs of Ivanovia from the Zhongxinzhai mound: micritized bioclastic packstone (MBP), clotted micrite (CM); $\mathbf{f}$ Details of the red box in (e)

skeletal grains, trap mud-size sediments, and form micritic envelopes (Fig. 8a, b).

Ortonella are found in the micritized bioclasticintraclastic wackestone of the Zhongxinzhai mound in a relatively low abundance. The closely-packet tubes are arranged parallel or radial and show minute shrub outlines (Fig. 8c, d). Individual tubes are $20-30 \mu \mathrm{m}$ in diameter, with microsparry or sparry calcite interiors and micritized sheaths. No clear branching of the tubes has been determined in this study although this could be attributed to the low abundance and poor preservation of the Ortonella.

Wetheredella is a calcareous encrusting porostromate, commonly developing in reefs from the Cambrian to the Permian age (Wood 1948; Riding 1991; Jarochowska and Munnecke 2014). Riding (1991) assigned the Wetheredella group to Porostromata. It generally co-occurs with
Girvanella and Rothpletzella. Jarochowska and Munnecke (2014) demonstrated the external, three-dimensional aspect of the Paleozoic incertae sedis sclerobiont Allonema and compared it with the diagnostic features of Wetheredella. The diagnosis of these two organisms is comparable. They proposed Wetheredella as a junior synonym of Allonema (Jarochowska and Munnecke 2014). A type of calcimicrobe, the common encrusting organism in the mounds recognized in this study, shows similar characteristics to those of Wetheredella and is called Wetheredella-like calcimicrobe. Wetheredella-like calcimicrobe tends to encrust a foreign body, such as bryozoans, crinoids, brachiopods, and calcareous algae (Fig. 9a, b). Two categories of Wetheredella-like calcimicrobe, the aggregate and the isolated types, have been observed. The aggregate form comprises intertwined and flexuous tubes. The vesicles show a sub-circular outline with a microsparry or sparry 

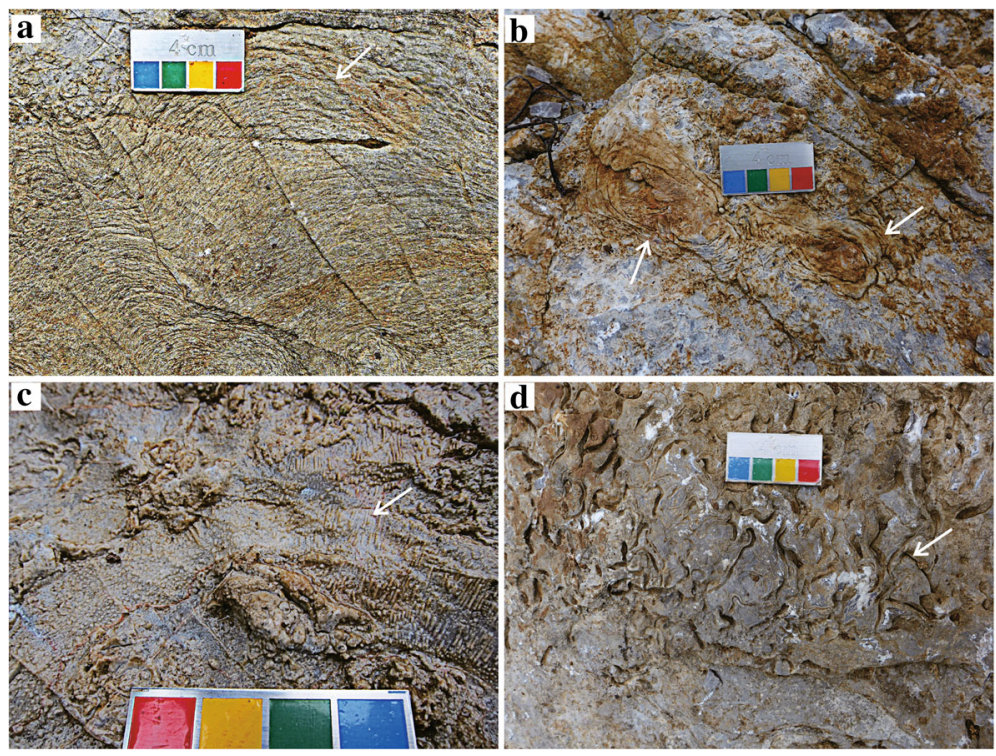

Fig. 4 Field photographs of the Lumazhai mound. a Stromatolitic boundstone (white arrow); b Irregular oncoid-like microbial boundstone (white arrows); c Chaetetids in Stage II (white arrow); d Phylloid algae boundstone in Stage III: well-preserved algal thalli (white arrow)

calcite interior and a micritized wall. The micrite is abundant in the Wetheredella-like aggregate form. The diameters of the individual Wetheredella-like vesicles are variable, from $100 \mu \mathrm{m}$ to $300 \mu \mathrm{m}$. The isolated type generally adheres to the hard substrate and possesses a microsparry or sparry calcite interior (Fig. 9c). The isolated vesicles are around $100 \mu \mathrm{m}$ in diameter.

The Palaeomicrocodium-like calcimicrobe is another type of calcimicrobe, mainly occurring in peloid-lithoclast packstone in the Zhongxinzhai mound. The defined Palaeomicrocodium exhibits a crystal rosette appearance with fibrous or bladed calcite (Mamet and Préat 1985; Antoshkina 2006, 2014). While the Palaeomicrocodiumlike calcimicrobe obtained from the Zhongxinzhai mound has a micrite center and ranges in diameter from $100 \mu \mathrm{m}$ to $300 \mu \mathrm{m}$ (Fig. 9d). Some specimens of Palaeomicrocodium from the Upper Devonian exhibit features similar to the features observed in this study (Antoshkina 2006,
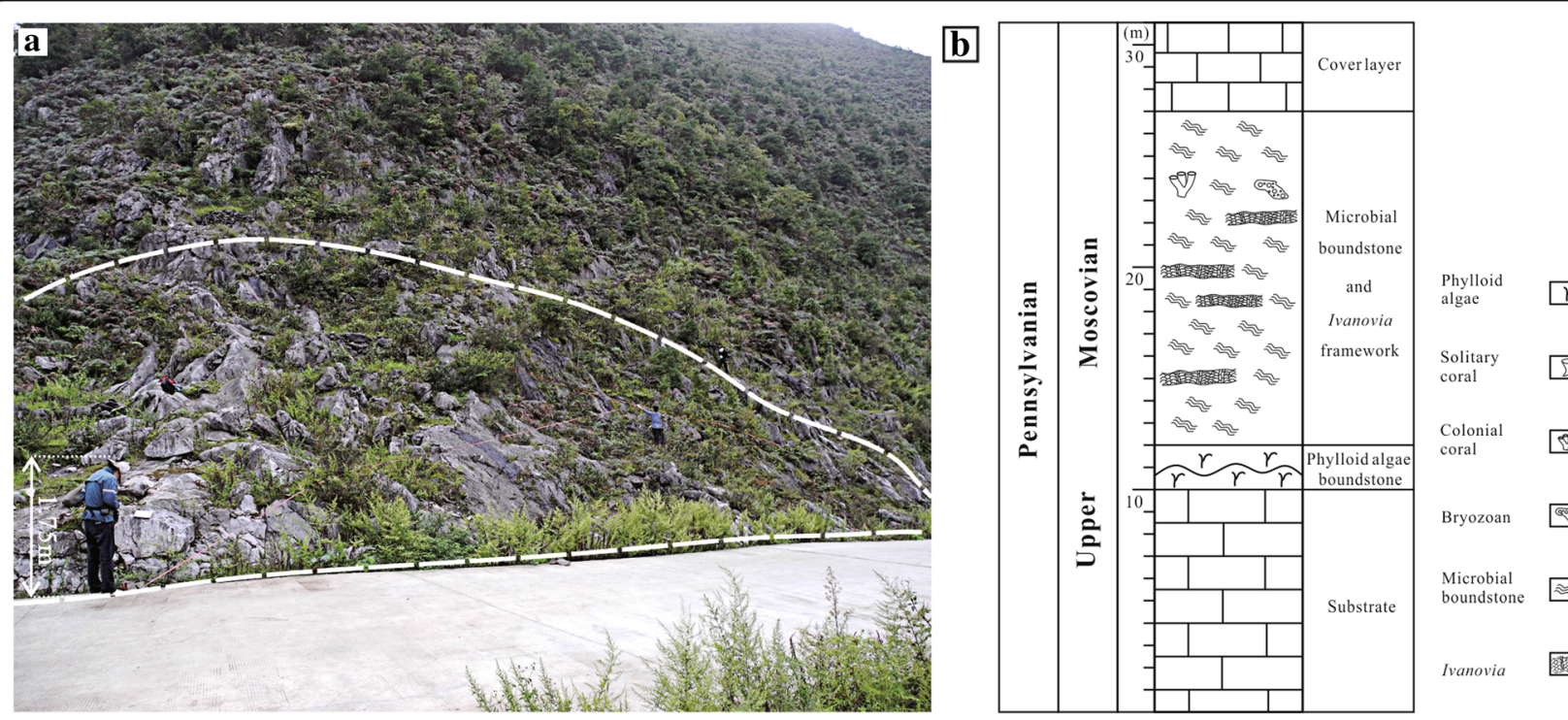

Fig. 5 Overview of the Zhongxinzhai mound. a Outcrop photography of the Zhongxinzhai mound; b Stratigraphic column of the Zhongxinzhai mound 

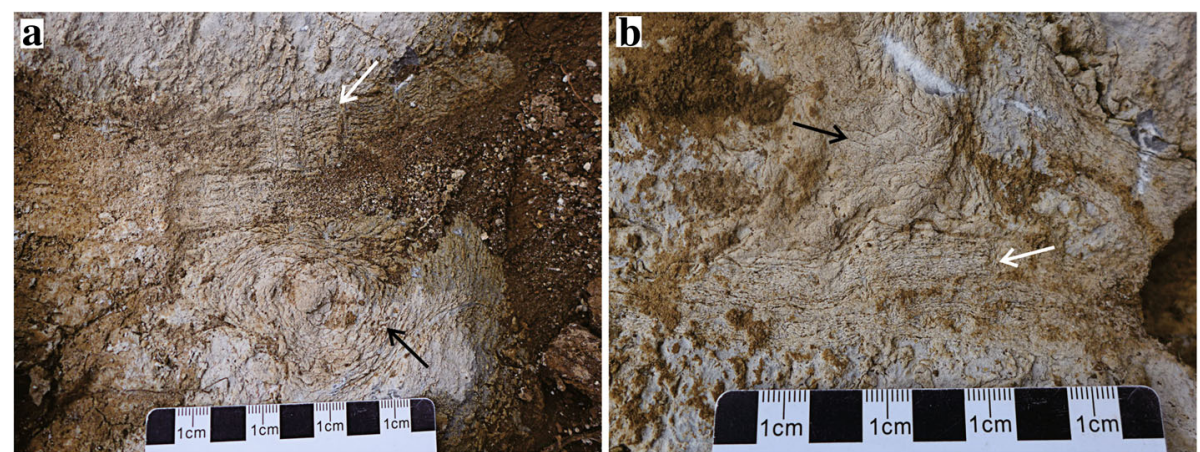

Fig. 6 Field photographs of the Zhongxinzhai mound. a Ivanovia (white arrow) grows on the microbial boundstone (black arrow); b Microbial boundstone (black arrow) covers the Ivanovia (white arrow)

2014). Palaeomicrocodium-like aggregates make up about $5 \%$ of the peloid-lithoclast packstone volume in the Zhongxinzhai mound.

\subsection{Microbial carbonates}

Microbial carbonates are the dominant component of the mounds, constituting the constructor, filler, and encruster. They generally occur as microbial fabrics, thrombolitic texture, microstromatolites, microbial ooids, oncoids, irregular layers of encrusters, microbial mat debris, and microbial micrite in the microbial boundstone, peloid wackestone-packstone, bioclastic-intraclastic wackestonepackstone, and phylloid algae boundstone.
Among microbial carbonates in the mounds, one dominant fabric is a type of unidentified algal-like boundstone. Its distinguishing feature is the stromatolitic internal structure, irregular oncoid-like form, and wrinkle structures on the weathered surface (Figs. 4a, b and $6 a, b)$. Three types of this unidentified microbial fabric have been recognized under the microscope: encrusting, laminar, and grid-shaped fabrics. The encrusting microbial fabric grows and extends along the surface of the substrate or encrusts a foreign body, forming dense or silk-like encrustation (Fig. 10a, b). The silk-like encrustation form generally exists between the substrate and the grid-shaped microbial fabrics. The grid-shaped microbial
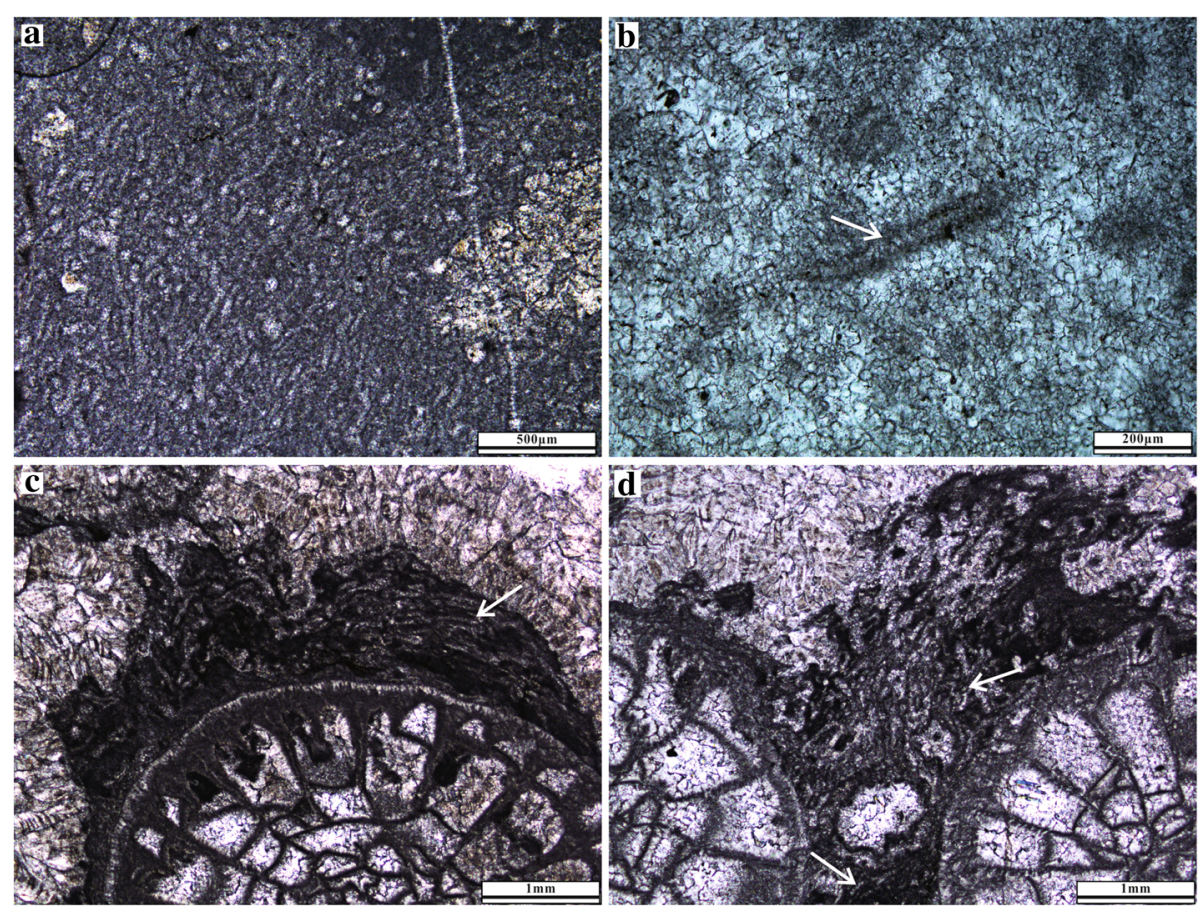

Fig. 7 Thin-section photographs of Girvanella. a Girvanella boundstone with micritic texture containing abundant tubular thalli; b Girvanella intraclasts (white arrow); c Girvanella (white arrow) crusts on coral; d Girvanella (white arrows) in coral frameworks, jointing the coral individuals 

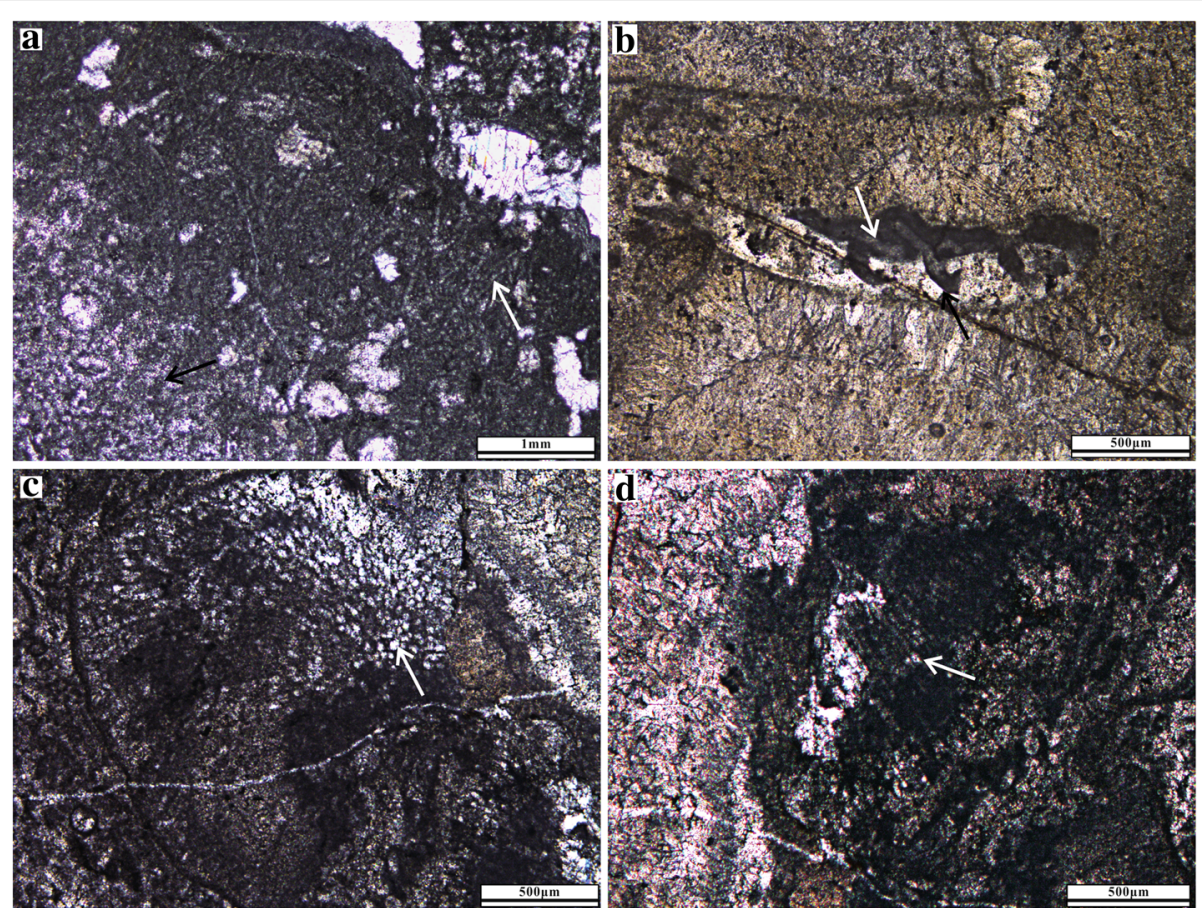

Fig. 8 Thin-section photographs of Girvanella and Ortonella. a Girvanella boundstone with micritic texture colonized by tubular thalli (white arrow) and the clotted micrite (black arrow); b Girvanella-like organisms bore shell: the thalli in the shell (black arrow) and encrusting the shell (white arrow); c Transection of Ortonella: tubes were filled of microsparry or sparry calcite (white arrow); d Longitudinal section of Ortonella, showing closely-packet tubes (white arrow)
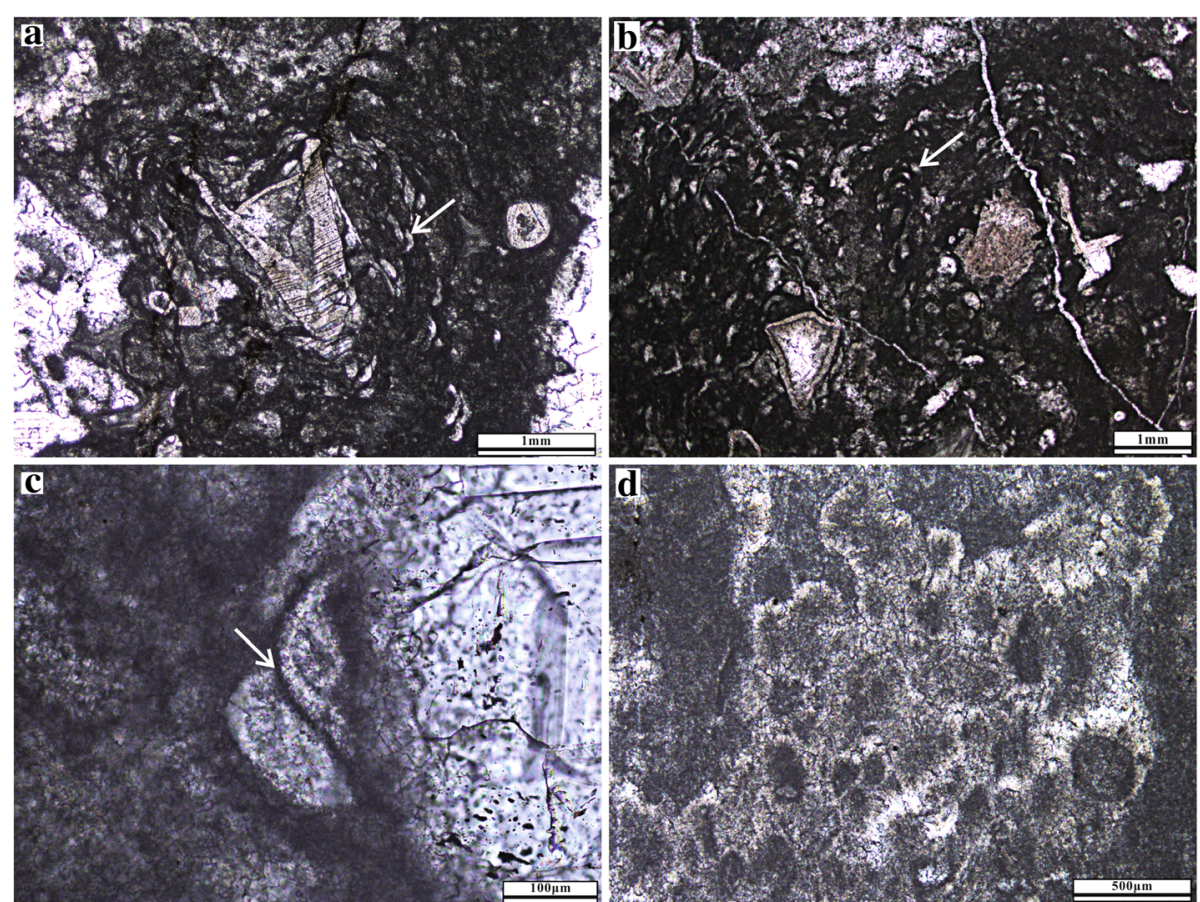

Fig. 9 Thin-section photographs of Wetheredella-like and Palaeomicrocodium-like calcimicrobes. a, b Aggregate Wetheredella-like calcimicrobe, encrusting a foreign body; c Isolated Wetheredella-like calcimicrobe (white arrow); d Palaeomicrocodium-like form 
fabric is composed of a thin micritic layer and an irregular fan-shaped grid consisting of fibrous marine cement, sparry calcite or clotted micrite (Fig. 10c, d), and commonly grows on the encrusting microbial fabric. Few fossils can be found in the grid-shaped microbial fabrics. The dark micrite laminar microbial fabrics are common in the grid-shaped microbial fabrics and are seen as thicker microbial mud layers than those in grid-shaped microbial fabrics, with characteristics that are similar to the encrusting form (Fig. 10b, d).

Thrombolitic textures are abundant and play vital roles in the substrate stabilization and the mound construction. Most types of bioclasts (e.g. bryozoans, crinoids, algae) in the substrate are encrusted by a dark-colored envelope of non-layered microbial filaments (Fig. 3b). In the mound, thrombolitic textures are important components, occurring as infillings between the algal-like microbial boundstone or as the substrate for the encrusting microbial fabric (Fig. 11a). The clotted microbial micrite is inter-grown with sparry cement (Fig. 11b) and is common in microbial boundstone and phylloid algae boundstone (Fig. 11c, d). In the Zhongxinzhai mound, Ivanovia and bryozoans commonly colonize on the thrombolitic wackestone and micritized-bioclast packstone (Figs. 11 and 12), and have impact on the mound construction.

Microstromatolites are common in the mounds (Fig. 12), generally occurring in the cavities between the algal-like microbial boundstone, in peloid wackestone-packstone, or in bioclastic-intraclastic wackestone-packstone. The microbial laminae normally grow on the thrombolitic mass, lithoclasts, and bioclasts such as crinoids, bryozoans, and corals. Two main types of microstromatolites, the domical and the cabbage-like (Fig. 12c, d), have been observed. Individual domical microstromatolites are generally $1-8 \mathrm{~mm}$ in width and $2-5 \mathrm{~mm}$ in height. The stromatolitic fabric commonly comprises micritic laminae and clotted microbial micrite with spar-filled interparticles (Fig. 12c, d). The cabbage-like fabric is usually $1-3 \mathrm{~mm}$ in diameter (Fig. 12d).

In the study area, oncoids and microbial ooids $(<2$ $\mathrm{mm}$ ) have been recognized. The oncoids are scattered in the peloid-bioclastic packstone in the cover layers of the Lumazhai mound, ranging from $1 \mathrm{~cm}$ to $3 \mathrm{~cm}$ in diameter. Bioclasts are common nuclei of the oncoids (Fig. 13a, b). In the Zhongxinzhai mound, some round or oval micritic grains with fuzzy radial structures or ill-defined laminated structures are locally abundant and co-occur with microbial boundstone, filling the cavities constructed by microbial boundstone. They generally mix with common peloids and vary in size from 0.5 $\mathrm{mm}$ to $1.5 \mathrm{~mm}$, showing poor sorting (Fig. 13c). Some tubular calcimicrobes are well preserved in these grains (Fig. 13d). These grains were described as microbial ooids by Flügel (2004).
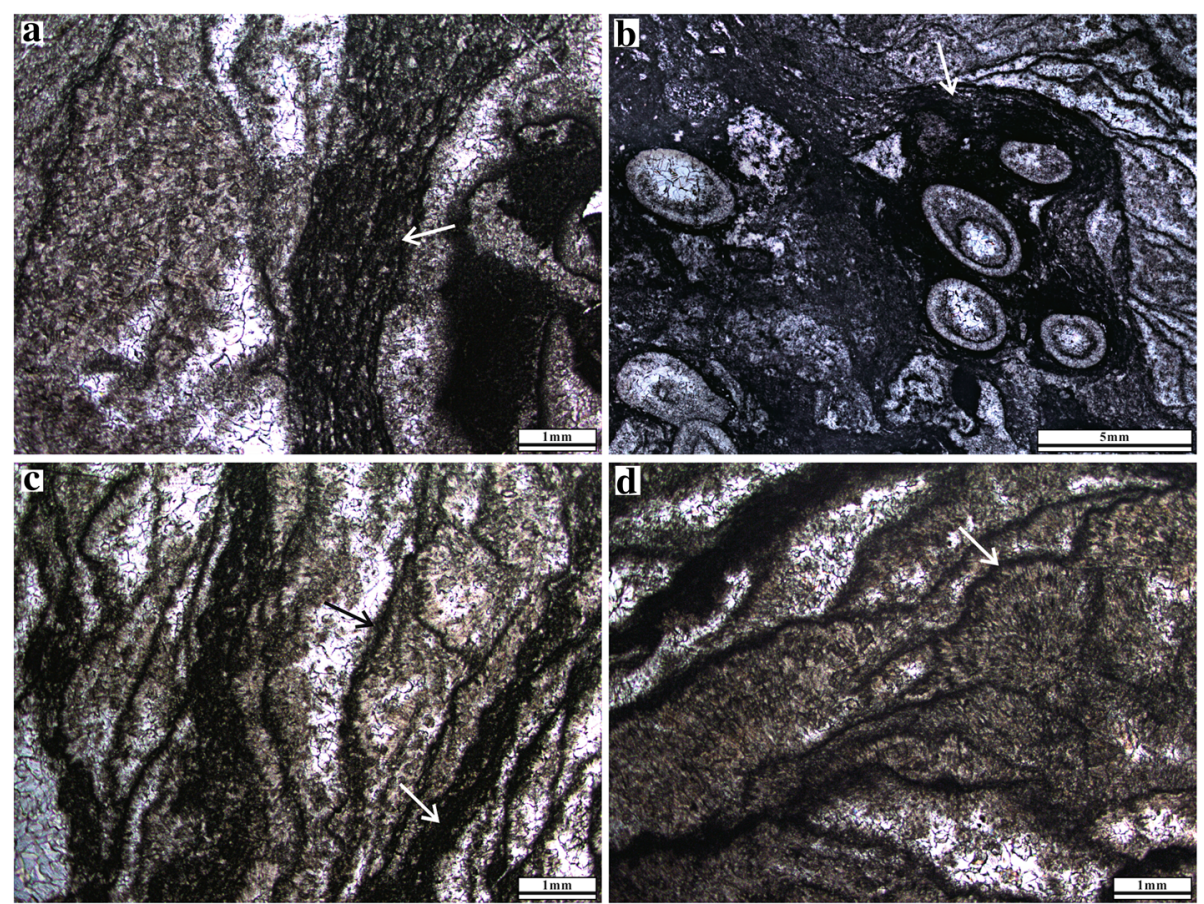

Fig. 10 Unidentified algal-like microbial fabrics. a Encrusting form (white arrow) with the fuzzy structure encrusting the thrombolitic clasts; b Encrusting form (white arrow) with the silk-like texture growing on the substrate surface, combining the tube organisms; $\mathbf{c}$ Laminar (white arrow) and grid-shaped (black arrow) microbial fabrics; d Grid-shaped unidentified microbial fabric with irregular fan-shaped grid consisting of fibrous marine cement and micritic layer (white arrow) 

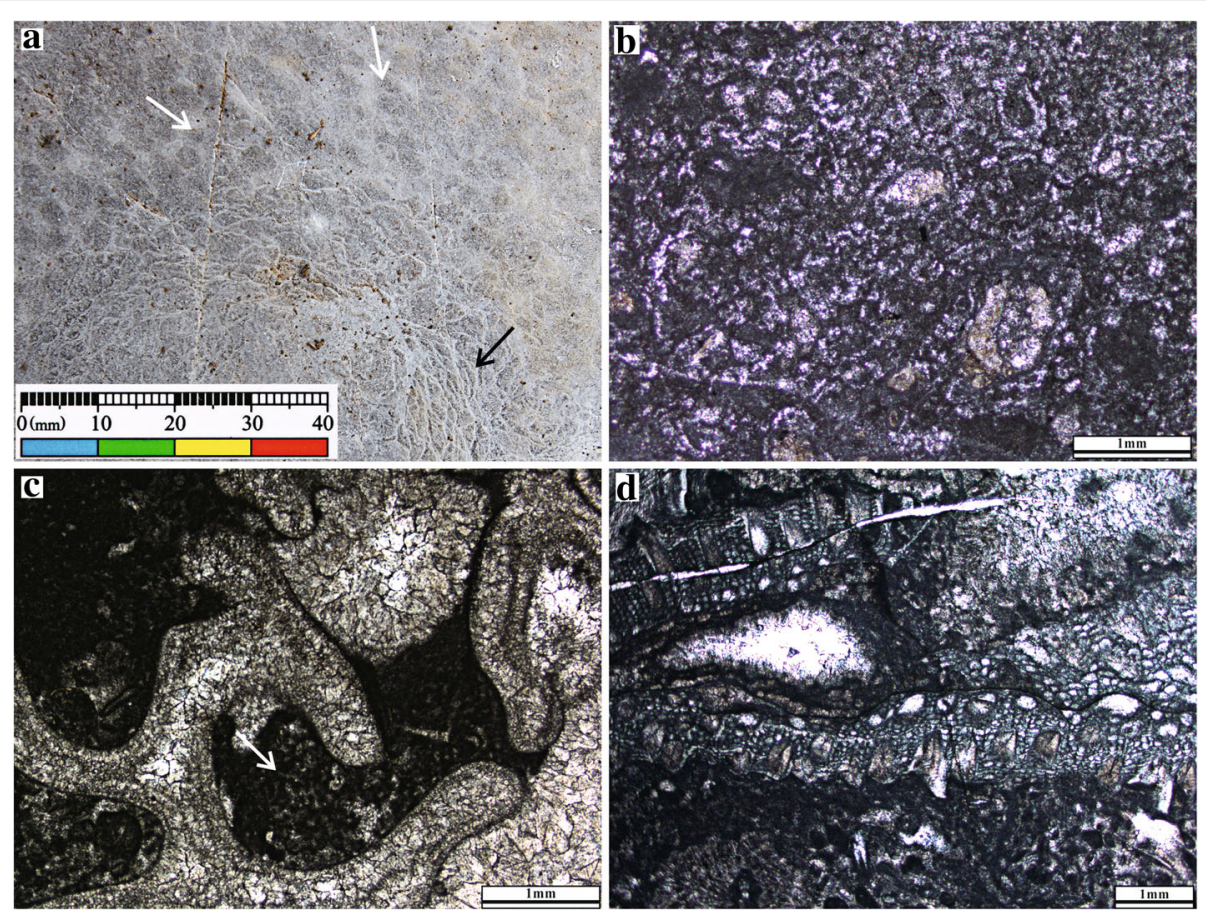

Fig. 11 Photographs of thrombolitic texture. a Field photograph of thrombolitic texture (white arrow) and wrinkle structure (black arrow) from the Zhongxinzhai mound; $\mathbf{b}$ Thin-section photograph of thrombolitic texture with clotted micrite; $\mathbf{c}$ Thin-section photograph of phylloid algae boundstone with abundant clotted micrite (white arrow); $\mathbf{d}$ Thin-section photograph shows bryozoan encrusting the substrate composing of micritized bioclasts from the Zhongxinzhai mound
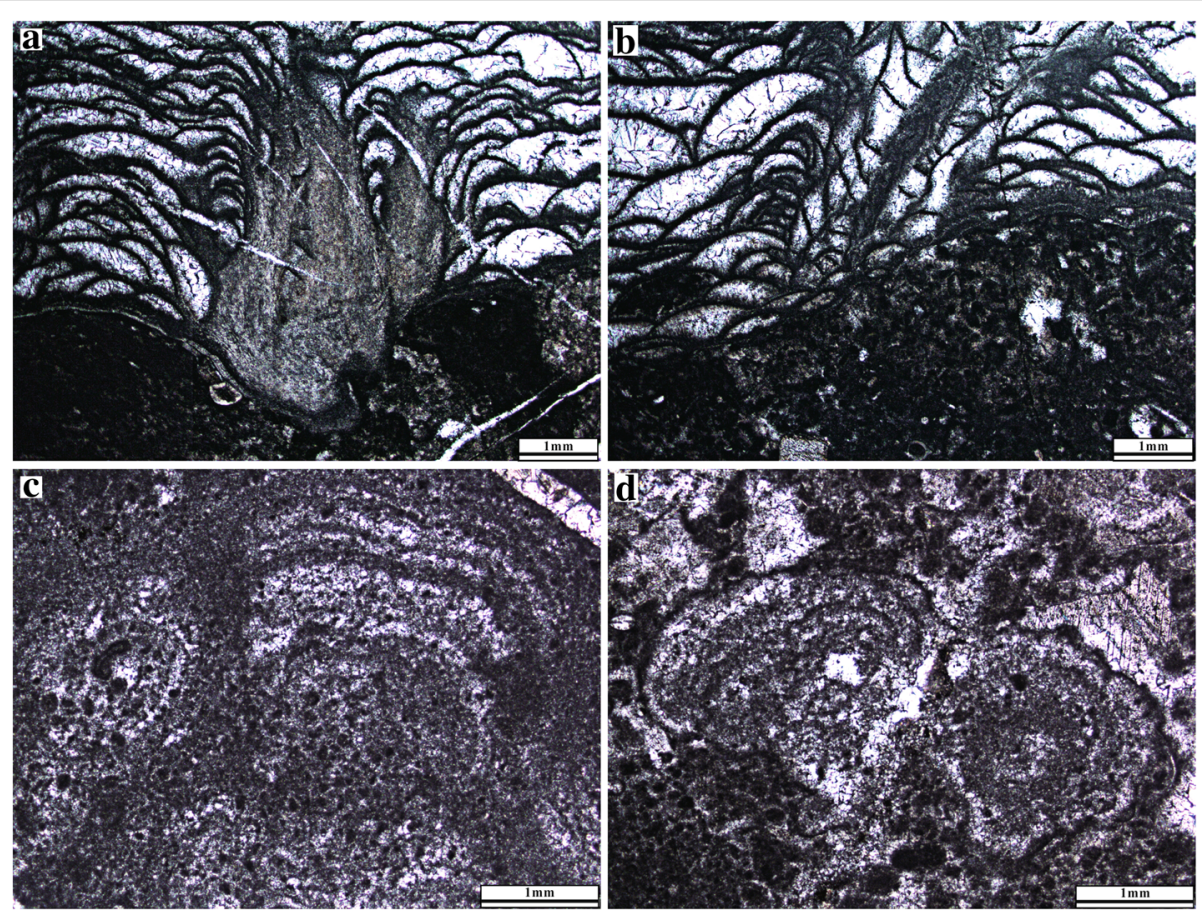

Fig. 12 Thin-section photographs of thrombolitic texture and microstromatolites. a, b Ivanovia colonizing on the thrombolitic wackestone with clotted micrite; c, d Microstromatolites in mounds co-occurring with clotted micrite 

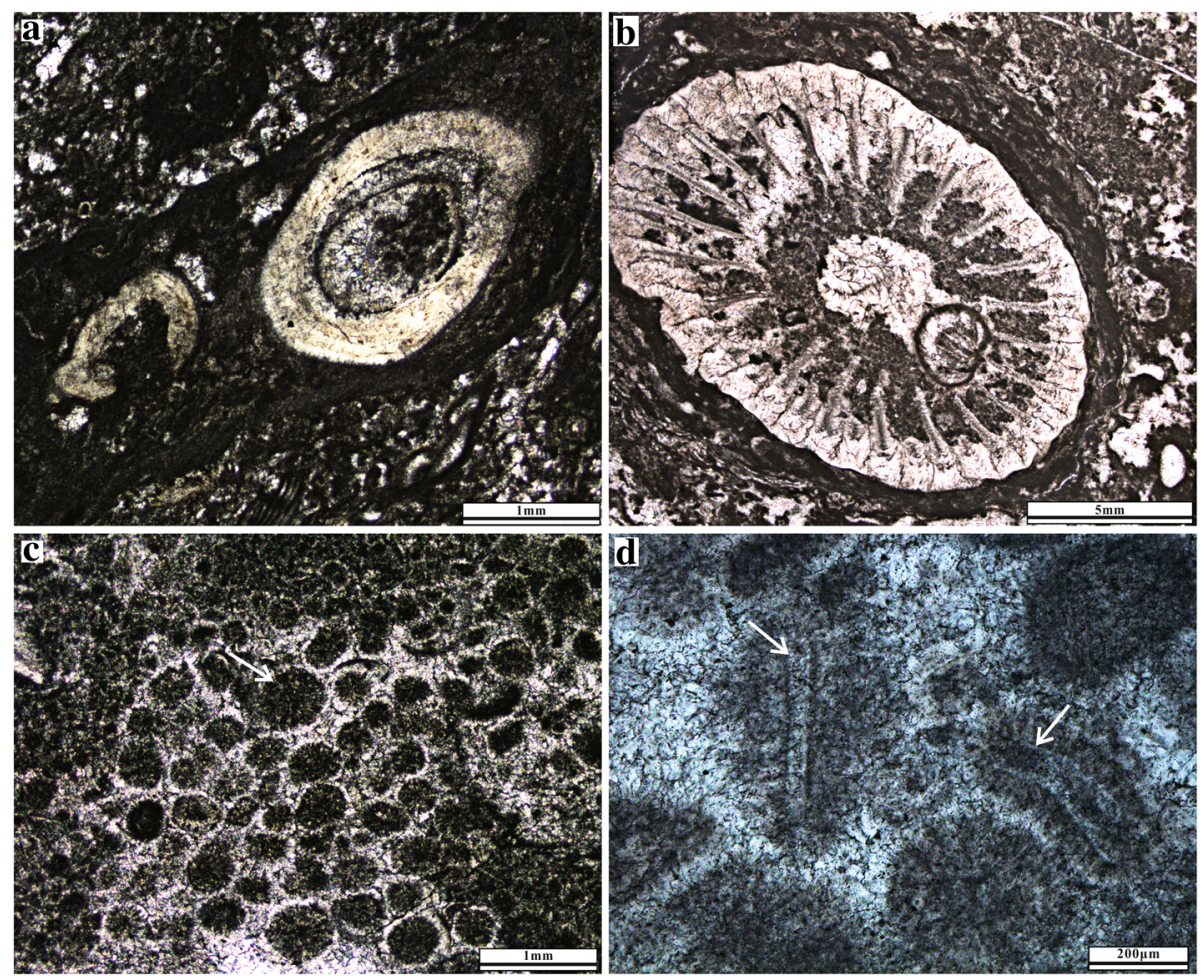

Fig. 13 Thin-section photographs of oncoids and microbial ooids. a, b Oncoids from the cover layer of the Lumazhai mound; c Microbial ooids from the Zhongxinzhai mound; $\mathbf{d}$ The tubular calcimicrobes in the microbial ooids, indicative of a microbial genesis

\section{Discussion}

Differentiated calcimicrobes and microbial carbonates are the dominant components in the Lumazhai and Zhongxinzhai mounds, and play a vital role in the construction of these mounds. Moreover, the irregular-shaped microbial boundstone with wrinkle structures (Figs. 4a, b and $6 \mathrm{a}, \mathrm{b})$, which could be attributed to unknown microbes, is the dominant component in the mounds. It can form mounds alone (Stage I of the Lumazhai mound) or co-build the mound with corals, crinoids, bryozoans, and sponges (Stage II of the Lumazhai mound; and Stage II of the Zhongxinzhai mound). The Zhongxinzhai mound is dominated by algal-like microbial boundstone and colonial rugose corals (Ivanovia), though an alternating encrusting growth pattern of microbial filaments and colonial rugose corals (Ivanovia) is common (Figs. 6 and 12). Ivanovia encrusts hard substrates and favors shallow, high-energy environments (Zhang et al. 2009). Carbonate hardgrounds (in situ), carbonate hardground clasts, and calcareous bioclasts are the common hard substrates for Ivanovia (Zhang et al. 2009). This alternating encrusting growth pattern implies that the microbial boundstone plays a vital part in mound construction and evolution, both as the main component and by providing a hard substrate for the coral. Numerous calcimicrobes, algae, corals, and bryozoans co-exist with this unidentified microbial boundstone, which may indicate that this irregular-shaped microbial boundstone was formed in the euphotic zone with shallow, normal salinity, and relatively high-energy conditions (Gong et al. 2007a; Zhang et al. 2009).

Girvanella and Girvanella-like tubiform fossils are the common calcimicrobes in the study area, which can be observed in thin sections from the Neoproterozoic to the Neogene (Christopher 1990; Riding 1991; Knoll et al. 1993; Pratt 2001; Chen et al. 2003; Adachi et al. 2006; Martin 2010; Liu and Zhang 2012; Rong et al. 2014). Pratt (2001) suggested that these filamentous cyanobacteria with rapid growth rates could produce a significant amount of lime mud in the marine environment. Girvanella is regarded as a main source of lime mud in the Lower Paleozoic by many researchers (Coniglio and James 1985; Pratt 2001; Liu and Zhang 2012; Rong et al. 2014). In this study, it occurs in four categories: Girvanella boundstone, Girvanella intraclasts, Girvanella crusts, and borer. The Girvanella in the boundstone and intraclasts is considered to be a contributor to the lime mud of the mound complexes (Pratt 2001; Rong et al. 2014). In the coral framework, in situ Girvanella encrusts the coral, binding individuals together, and fills the growth space, which fulfils a critical effect on the coral frame stabilization.

Thrombolitic textures and other microbial mats are common in the substrate and interior of the mounds, and 
may play significant roles in trapping and fixing sediments and bioclasts, contributing to the stabilization of mound limestones (Shen and Webb 2008). Having micritic envelopes on the skeletal grains is one of the significant features in the mounds. Microboring, a critical process in the micritic envelope formation, is common on these skeletal grains. Perforation is a destruction process for the skeletal grains when the microbes colonized their surface (Klement and Toomey 1967; Macintyre et al. 2000; Reid et al. 2000; Hillgärtner et al. 2001). The boring algae (e.g. Girvanella) are thought to be a major agent in the early diagenetic grains breakdown in carbonate sediments (Klement and Toomey 1967). Boring is important in the carbonate alteration and destruction, and the formation of silt and micrite-size materials (Klement and Toomey 1967; Kobluk and Risk 1977). Meanwhile, the micritic envelopes are more resistant to dissolution during diagenesis than most skeletal grains (Friedman et al. 1971). The crusts and the micritic envelopes could help to preserve the original shapes of skeletal particles in diagenetic processes (Friedman et al. 1971; Rong et al. 2014).

The mounds in this study are the earliest known Late Carboniferous organism buildups in southern Guizhou, with a Moscovian age. They are distinct from the Waulsortian mounds in the Mississippian (Lees 1961, 1964, 1997; Miller 1986). Waulsortian mounds are dominated by mud and conspicuously lack rigid organic skeletal framework, though fossils (e.g., crinoids, bryozoans, brachiopods, and molluscs) are common in some facies (Lees and Miller 1995). In the study area, calcimicrobes, algae and a few skeletal metazoans (e.g., Ivanovia, bryozoans, and sponges) co-construct the mounds. These mounds also differ considerably from most previously described Moscovian reefs developed in other areas (e.g., America, Suchy and West 1988, 2001; Japan, Nakazawa 2001; North China, Wang et al. 2017, Zhang et al. 2018). During the Moscovian, chaetetid reefs were conspicuous, as sponges became notable frame-builders (West 1988). Chaetetids are widely distributed and are the main builders of Moscovian reefs in North China, Japan, and America, which commonly form biostromes and patch reefs (Suchy and West 1988, 2001; West 1988; Nakazawa 2001; Wang et al. 2017). In South China, Moscovian metazoan reefs are rarely documented. Only a few coral biostro$\mathrm{mal} / \mathrm{patch}$ reefs have been reported in the Huanglong Formation, in Guangxi (Yang et al. 2013, 2014). The buildups formed by chaetetids are still absent. In this study, calcimicrobes and algae are the main builders of the Moscovian mounds, which may indicate that calcimicrobes and algae were thriving and acted as the primary mound builders during the Late Carboniferous in South China.

\section{Conclusions}

1) The mounds described in this study belonged to the Late Moscovian, and were characterized by various microbial fabrics. The irregular-shaped microbial boundstone with wrinkle structures was the dominant component of the mounds, and could be attributed to unknown microbes. It co-existed with numerous calcimicrobes, corals, bryozoans, and sponges, which might be formed in the euphotic zone with shallow water, normal salinity, and relatively high-energy conditions.

2) Various calcimicrobes, including Girvanella, Ortonella, Wetheredella-like, Palaeomicrocodium-like, Tubiphytes-like organisms, and problematic calcimicrobe organisms, were recognized in the limestones of the mounds. Microbial carbonates constituted a large volume of the mounds and were present in different types, including thrombolites, microstromatolites, encrustations, microbial ooids, oncoids, and microbial micrite. Calcimicrobes and microbial carbonates played a vital role in mound construction and evolution.

3) Calcimicrobes and algae were the main builders of the mounds in this study, which were considerably different from those in other areas, where chaetetid reefs were more conspicuous during the Moscovian. These possibly indicated that calcimicrobes and algae were thriving and acted as the primary mound builders during the Moscovian in South China.

\section{Acknowledgements \\ The authors thank Prof. Zeng-Zhao Feng for his helpful comments and Prof. Robert Riding for his help on the calcimicrobe identification.}

\section{Authors' contributions}

WTH and EPG conceived the idea of the study and wrote the paper. YLZ and CQG interpreted the results and revised the manuscript. ZWM, XHC, ZYY and $\mathrm{XL}$ processed the samples, discussed the results and revised the manuscript. All authors read and approved the final manuscript.

\section{Funding}

This study was supported by the National Natural Science Foundation of China (Grant No. 41572004).

\section{Availability of data and materials}

The datasets used during the current study are available from the corresponding author on reasonable request.

\section{Competing interests}

The authors declare that they have no competing interests.

\section{Author details}

${ }^{1}$ College of Resources and Civil Engineering, Northeastern University, Shenyang 110819, Liaoning Province, China. ${ }^{2}$ College of Resources and Materials, Northeastern University at Qinhuangdao, Qinhuangdao 066004, Hebei Province, China.

Received: 30 October 2018 Accepted: 13 June 2019

Published online: 31 July 2019

\section{References}

Adachi, N., Y. Ezaki, and J.W. Pickett. 2006. Marked accumulation patterns characteristic of Lower Devonian stromatoporoid bindstone: Palaeoecological interactions between skeletal organisms and microbes. Palaeogeography, Palaeoclimatology, Palaeoecology 231 (3): 331-346.

Antoshkina, A.I. 2006. Palaeoenvironmental implications of Palaeomicrocodium in Upper Devonian microbial mounds of the Chernyshev Swell, TimanNorthern Ural Region. Facies 52 (4): 611-625. 
Antoshkina, A.l. 2014. Palaeomicrocodium: A new view on its origin. Paleontological Journal 48 (4): 353-368.

Aretz, M., E. Poty, F.-X. Devuyst, L. Hance, and H.-F. Hou. 2012. Late Tournaisian Waulsortian-like carbonate mud banks from South China (Longdianshan Hill, central Guangxi): Preliminary investigations. Geological Journal 47 (5): 450-461.

Bureau of Geology and Mineral Resources of Guizhou Province. 1987. Regional Geology of Guizhou Province. Beijing: Geological Publishing House (in Chinese).

Chen, X.-H., E.-P. Gong, T.-H. Wang, C.-Q. Guan, Y.-L. Zhang, D.-Y. Yang, and H.-M. Wang. 2013. The basic characteristics of Early Carboniferous coral reef at Xiadong Village in Tianlin, Guangxi, and its sedimentary environment. Acta Geologica Sinica 87 (5): 597-608 (in Chinese with English abstract).

Chen, Z.-Q., G.R. Shi, and W.-R. Yang. 2003. Internal structure and paleoecology of the lower Permian Uzunbulak reef complex of the Tarim Basin, Northwest China. Facies 49 (1): 119-134.

Chevalier, E., and M. Aretz. 2005. A microbe-bryozoan reef from the middle Viséan of the Namur Syncline (Engihoul Quarry). Geologica Belgica 8 (1): 109-119.

Christopher, C.C. 1990. Late Mississippan Girvanella-bryozoan mud mounds in southern West Virginia. Palaios 5 (5): 460-471.

Coniglio, M., and N.P. James. 1985. Calcified algae as sediment contributors to early Paleozoic limestones: Evidence from deep-water sediments of the Cow Head Group, Western Newfoundland. Journal of Sedimentary Research 55 (5): 746-754.

Fagerstrom, J.A. 1994. The history of Devonian-Carboniferous reef communities: Extinctions, effects, recovery. Facies 30 (1): 177-191.

Fang, S.-X., and F.-H. Hou. 1985. Bryozoan-coral patch reef of Datang age of Carboniferous period of Langping area, Tianlin County, Guangxi Province. Journal of Southwestern Petroleum Institute 4: 4-8 (in Chinese with English abstract).

Feng, Z.-Z., Y.-Q. Yang, and Z.-D. Bao. 1999. Lithofacies palaeogeography of the Carboniferous in South China. Journal of Palaeogeography (Chinese Edition) 1 (1): 75-86 (in Chinese with English abstract).

Flügel, E. 2004. Microfacies of Carbonate Rocks: Analysis, Interpretation and Application. Berlin Heidelberg, Dordrecht: Springer-Verlag.

Friedman, G.M., C.D. Gebelein, and J.E. Sanders. 1971. Micritic envelopes of carbonate grains are not exclusively of photosynthetic algal origin. Sedimentology 16 (1-2): 89-96.

Gong, E.-P., E. Samankassou, C.-Q. Guan, Y.-L. Zhang, and B.-L. Sun. 2007a. Paleoecology of Pennsylvanian phylloid algal buildups in South Guizhou, China. Facies 53: 615-623.

Gong, E.-P., H.-Y. Yang, C.-Q. Guan, B.-L. Sun, and Y.-Z. Yao. 2004. Unique recovery stage of reef communities after $F / F$ event in a huge coral reef of Carboniferous, southern Guizhou, China. Science China Earth Sciences 47 (5): 412-418.

Gong, E.-P., Y.-L. Zhang, C.-Q. Guan, and X.-H. Chen. 2012. The Carboniferous reefs in China. Journal of Palaeogeography 1 (1): 27-42.

Gong, E.-P., Y.-L. Zhang, C.-Q. Guan, E. Samankassou, and B.L. Sun. 2007b. Paleoecology of Late Carboniferous phylloid algae in southern Guizhou, SW China. Acta Geologica Sinica (English Edition) 81 (4): 566-572.

Gong, E.-P., Y.-L. Zhang, C.-Q. Guan, and B.-L. Sun. 2010. Main features of the Carboniferous organic reefs in the world. Journal of Palaeogeography (Chinese Edition) 12 (2): 127-139 (in Chinese with English abstract).

Guan, C.-Q., E.-P. Gong, Y.-Z. Yao, and B.-L. Sun. 2004. Biocoenose community analysis of Bianping reefs of the Late Carboniferous in southern Guizhou Province. Journal of Palaeogeography (Chinese Edition) 6 (3): 339-346 (in Chinese with English abstract).

Guan, C.-Q., E.-P. Gong, Y.-Z. Yao, and B.-L. Sun. 2006. Palaeoecological characteristic of Ivanovia cf. manchurica coral and the reef mechanism of the Late-Carboniferous in the South of Guizhou Province. Geological Review 52 (2): 178-183 (in Chinese with English abstract).

Guan, C.-Q., E.-P. Gong, Y.-Z. Yao, B.-L. Sun, and H.-L. Chang. 2010. Tubiphytes in reef strata of the late Carboniferous in South Guizhou Province. Acta Sedimentologica Sinica 28 (2): 219-226 (in Chinese with English abstract).
Guan, C.-Q., E.-P. Gong, Y.-L. Zhang, B.-L. Sun, H. Chen, J.-H. Guo, and Q. Li. 2007. A new type reef of the Late Carboniferous in the south of Guizhou Province. Geological Review 53 (4): 433-439 (in Chinese with English abstract).

Hillgärtner, H., C. Dupraz, and W. Hug. 2001. Microbially induced cementation of carbonate sands: Are micritic meniscus cements good indicators of vadose diagenesis? Sedimentology 48 (1): 117-131.

Jarochowska, E., and A. Munnecke. 2014. The Paleozoic problematica Wetheredella and Allonema are two aspects of the same organism. Facies 60 (2): 651-662.

Klement, K.W., and D.F. Toomey. 1967. Role of the blue-green alga Girvanella in skeletal grain destruction and lime-mud formation in the Lower Ordovician of West Texas. Journal of Sedimentary Research 4: 1045-1051.

Knoll, A.H., I.J. Fairchild, and K. Swett. 1993. Calcified microbes in Neoproterozoic carbonates: Implications for our understanding of the Proterozoic/Cambrian transition. Palaios 8 (6): 512-525.

Kobluk, D.R., and M.J. Risk. 1977. Calcification of exposed filaments of endolithic algae, micrite envelope formation and sediment production. Journal of Sedimentary Petrology 47 (2): 517-528.

Lees, A. 1961. The Waulsortian "reefs" of Eire: A carbonate mudbank complex of Lower Carboniferous age. The Journal of Geology 69: 101-109.

Lees, A. 1964. The structure and origin of the Waulsortian (Lower Carboniferous) 'reefs' of West-Central Eire. Philosophical Transactions of the Royal Society of Landon, Series B, Biological Sciences 247 (740): 483-531.

Lees, A. 1997. Biostratigraphy, sedimentology and palaeobathymetry of Waulsortian buildups and peri-Waulsortian rocks during the late Tournaisian regression, Dinant area, Belgium. Geological Journal 32: $1-36$.

Lees, A., and J. Miller. 1995. Waulsortian banks. In Carbonate mud-mounds: Their origin and evolution. The International Association of Sedimentologists: special publication, ed. C.L.V. Monty, D.W.J. Bosence, P. H. Bridge, and B.R. Pratt, No. 23, 191-271.

Liu, W., and X.-L. Zhang. 2012. Girvanella-coated grains from Cambrian oolitic limestone. Facies 58 (4): 779-787.

Liu, Z.-H. 2002. On factors of Carboniferous reef developing in Hunan: A comparing study with Akiyoshi reef in Japan. Chinese Journal of Geology 37 (1): 38-46 (in Chinese with English abstract).

Macintyre, I.G., L. Prufert-Bebout, and R.P. Reid. 2000. The role of endolithic cyanobacteria in the formation of lithified laminae in Bahamian stromatolites. Sedimentology 47 (5): 915-921.

Mamet, B., and A. Préat. 1985. Sur la présence de Palaeomicrocodium (Algue?, Incertae sedis?) dans le Givétien inférieur de Belgique. Géobios 18 (3): 389-395.

Martin, J.P.S. 2010. The Girvanella-like remains from Messinian marine deposits (Sardinia, Italy): Lagerstätten paradigm for microbial biota? Annales de Paléontologie 96 (2): 33-50.

Miller, J. 1986. Facies relationships and diagenesis in Waulsortian mudmounds from the Lower Carboniferous of Ireland and N. England. In Reef Diagenesis, ed. J.H. Schroeder and B.H. Purser, 311-335. Berlin, Heidelberg, New York, London, Paris, Tokyo: Springer-Verlag.

Nakazawa, T. 2001. Carboniferous reef succession of the Panthalassan open-ocean setting: Example from Omi limestone, Central Japan. Facies 44 (1): 183-210.

Pratt, B.R. 2001. Calcification of cyanobacterial filaments: Girvanella and the origin of Lower Paleozoic lime mud. Geology 29 (9): 763-766.

Reid, R.P., P.T. Visscher, A.W. Decho, J.F. Stolz, B.M. Bebout, C. Dupraz, I. G. Macintyre, H.W. Paerl, J.L. Pinckney, L. Prufert-Bebout, T.F. Steppe, and D.J. DesMarals. 2000. The role of microbes in accretion, lamination and early lithification of modern marine stromatolites. Nature 406 (6799): 989-992.

Riding, R. 1977. Calcified plectonema (blue-green algae), a recent example of Girvanella from Aldabra Atoll. Palaeontology 20 (1): 33-46.

Riding, R. 1991. Calcified Cyanobacteria. In Calcareous Algae and Stromatolites, ed. R. Riding, 55-87. Berlin, Heidelberg, New York, London Paris, Tokyo, Hong Kong, Barcelona: Springer-Verlag. 
Rong, H., Y.-Q. Jiao, Y.-B. Wang, L.-Q. Wu, and R. Wang. 2014. Distribution and geologic significance of Girvanella, within the Yijianfang Ordovician reef complexes in the Bachu area, West Tarim Basin, China. Facies 60 (2): 685-702.

Shen, J.-W., and H.-R. Qing. 2010. Mississippian (Early Carboniferous) stromatolite mounds in a fore-reef slope setting, Laibin, Guangxi, South China. International Journal of Earth Sciences 99 (2): 443-458.

Shen, J.-W., and G.E. Webb. 2008. The role of microbes in reef-building communities of the Cannindah limestone (Mississippian), Monto region, Queensland, Australia. Facies 54 (1): 89-105.

Suchy, D.R., and R.R. West. 1988. A Pennsylvanian cryptic community associated with laminar chaetetid colonies. Palaios 3 (4): 404-412.

Suchy, D.R., and R.R. West. 2001. Chaetetid buildups in a Westphalian (Desmoinesian) cyclothem in Southeastern Kansas. Palaios 16 (5): 425-443.

Sun, B.-L., E.-P. Gong, C.-Q. Guan, Y.-Z. Yao, and Y.-L. Zhang. 2007. Sedimentary environment and microfacies analysis of a Carboniferous coral reef in the Bianping village of Ziyun County, Guizhou. Acta Sedimentologica Sinica 25 (3): 351-357 (in Chinese with English abstract).

Wang, D., Y.-L. Zhang, E.-P. Gong, C.-Q. Guan, J. Wang, W.-T. Huang, Z.-W. Miao, M.-X. Ruan-Shi, Q. Chen, and X. Li. 2017. Growth morphology of chaetetids and buildup of Late Carboniferous reefs along the Taizi River, Eastern Liaoning. Acta Geologica Sinica 91 (10): 2309-2321 (in Chinese with English abstract).

Wang, J.-B., Y. Li, L. Cheng, X.-W. Zeng, and G. Wang. 2014. Paleozoic reefs and their paleogeological controls in South China Block. Acta Palaeontologica Sinica 53 (1): 121-131 (in Chinese with English abstract).

Webb, G.E. 2002. Latest Devonian and Early Carboniferous reefs: Depressed reef building after the middle Paleozoic collapse. In Phanerozoic Reef Patterns. SEPM: Special Publication, ed. E. Flugel, W. Kiessling, and J. Golonka, vol. 72, 239-269.

West, R.R. 1988. Temporal changes in Carboniferous reef mound communities. Palaios 3 (2): 152-169.

Wood, A. 1948. "Sphaerocodium," a misinterpreted fossil from the Wenlock limestone. Proceedings of the Geologists' Association 59: 9-22 4pls.

Wood, A. 1957. The type-species of the genus Girvanella (calcareous algae). Palaeontology 1 (1): 22-28.

Wu, X.-H. 1987. The Carboniferous biostratigraphy of Guizhou province, China Acta Geologica Sinica 4: 285-295 (in Chinese with English abstract).

Yang, D.-Y., E.-P. Gong, X.-H. Chen, and C.-Q. Guan. 2014. Comparison of the Late Carboniferous reef community ecosystem in Guizhou and Guangxi. Journal of Northeastern University (Natural Science) 35 (1): 107-111 (in Chinese with English abstract).

Yang, D.-Y., E.-P. Gong, B.-L. Sun, X.-H. Chen, C.-Q. Guan, and Y.-L. Zhang. 2013. Longjiangdong coral reef palaeoecology of the Upper Carboniferous Huanglong Formation in Tianlin County, Guangxi Province. Acta Sedimentologica Sinica 31 (3): 404-412 (in Chinese with English abstract).

Yao, L., and X.-D. Wang. 2016. Distribution and evolution of Carboniferous reefs in South China. Palaeoworld 25 (3): 362-376.

Yao, L., X.-D. Wang, W. Lin, Y. Li, S. Kershaw, and W.-K. Qie. 2016. Middle Viséan (Mississippian) coral biostrome in central Guizhou, Southwestern China and its palaeoclimatological implications. Palaeogeography, Palaeoclimatology. Palaeoecology 448 (SI): 179-194.

Zeng, D.-Q. 1996. A synopsis of oil field from Carboniferous algal reefs at Beibu Gulf. In The ancient organic reefs of China and their relations to oil and gas, ed. J.-S. Fan, 152-156. Beijing: Ocean Press (in Chinese).

Zhang, L.-X., and J.-P. Zhou. 2004. Late Carboniferous fusulinids from the type section of Dalaan stage in China. Acta Palaeontologica Sinica 43 (4): 515-529 (in Chinese with English abstract).

Zhang, Y.-L., E.-P. Gong, C.-Q. Guan, E. Samankassou, and B.-L. Sun. 2007. Carboniferous phylloid algal reefs in Ziyun County, Guizhou (South China): Evidence of algal blooms. Acta Sedimentologica Sinica 25 (2): 177-182 (in Chinese with English abstract).

Zhang, Y.-L., E.-P. Gong, M.A. Wilson, C.-Q. Guan, X.-H. Chen, W.-T. Huang, D. Wang, and Z.-W. Miao. 2018. Palaeoecology of late Carboniferous encrusting chaetetids in North China. Palaeobiodiversity and Palaeoenvironments 98: 205-223.
Zhang, Y.-L., E.-P. Gong, M.A. Wilson, C.-Q. Guan, B.-L. Sun, and H.-L. Chang 2009. Paleoecology of a Pennsylvanian encrusting colonial rugose coral in South Guizhou, China. Palaeogeography, Palaeoclimatology, Palaeoecology 280 (3): 507-516.

Zhou, H.-L., and Z.-X. Zhang. 1991. The early Carboniferous stromatolitic algal reef in Laibin County. Guangxi. Geology of Guangxi 4 (4): 1-5 (in Chinese with English abstract).

\section{Publisher's Note}

Springer Nature remains neutral with regard to jurisdictional claims in published maps and institutional affiliations.

\section{Submit your manuscript to a SpringerOpen ${ }^{\circ}$ journal and benefit from:}

- Convenient online submission

- Rigorous peer review

- Open access: articles freely available online

- High visibility within the field

- Retaining the copyright to your article

Submit your next manuscript at $>$ springeropen.com 